\title{
Разрушение волоконных световодов с полой сердцевиной под действием лазерного излучения
}

\author{
А.Н. Колядин ${ }^{*}$, А.Ф. Косолапов, И.А. Буфетов \\ Научный центр волоконной оптики РАН \\ *E-mail: antonkolyadin@gmail.com
}

DOI:10.31868/RFL2018.88-89

Впервые наблюдался процесс распространения волны разрушения по волоконному световоду с полой сердцевиной, заполненной воздухом, под действием лазерного излучения. В световод с диаметром полой сердцевины 20 мкм вводилось излучение импульсного неодимового одномодового лазера. Средняя скорость движения волны разрушения составляла $\sim 0.8$ м/с при средней мощности излучения около 2 Вт.

Распространение лазерной волны разрушения наблюдалось ранее в волоконных световодах различного типа с твердотельной сердцевиной. В световодах на основе кварцевого стекла при сравнительно низких интенсивностях излучения в сердцевине данное явление получило название fuse effect [1]. При повышении интенсивности теплопроводностный, медленный, режим распространения оптического разряда переходил в быстрый, детонационный [2]. В случае халькогенидных и флюоридных световодов наблюдалось полное разрушение световодов вместе с оболочкой при одновременном химическом взаимодействии материала световодов с атмосферными газами [3]. В настоящей работе исследовался процесс разрушения световодов (из кварцевого стекла) с полой сердцевиной револьверного типа. Вид поперечного сечения такого световода представлен на Рис.1d.
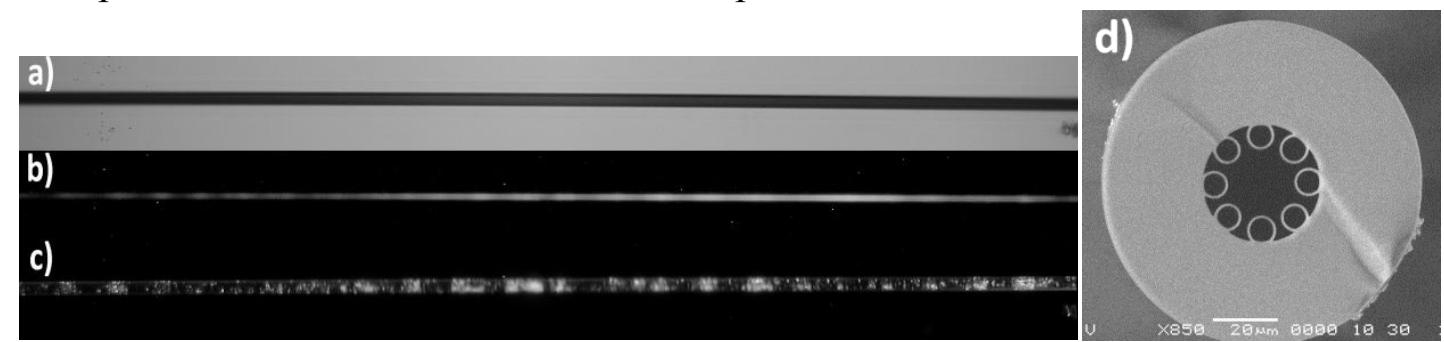

Рис.1 Фотографии световода. Вид сбоку (a-c). Размер по горизонтали - 3,5 мм. Сверху вниз: a) световод до разрушения, b) световод во время разрушения, снятый камерой с открытым затвором, с) световод после разрушения; d) фотография поперечного сечения световода.

Фотографии сделаны с помощью оптического микроскопа (рис.1, a-c). Световод был зачищен от полимерного покрытия и помещён в иммерсионную жидкость, поэтому внешние границы световода не видны. Фотографии на рис. 1a-c получены при одном увеличении и отображают один и тот же участок световода до, во время и после разрушения. Фотографии на рис.1а и 1с получены с оптимальной для каждого случая выдержкой при подсветке снизу (рис.1а) и сбоку (рис.1c). Фото на рис.1b сделано без подсветки при открытом на все время прохождения волны разрушения по световоду затворе. На рис. 1а ширина темной 
горизонтальной полосы соответствует внутреннему диаметру стеклянной оболочки (рис. 1d). Области повышенной яркости на рис.1b соответствуют областям с большей степенью разрушения капилляров на рис. 1c.

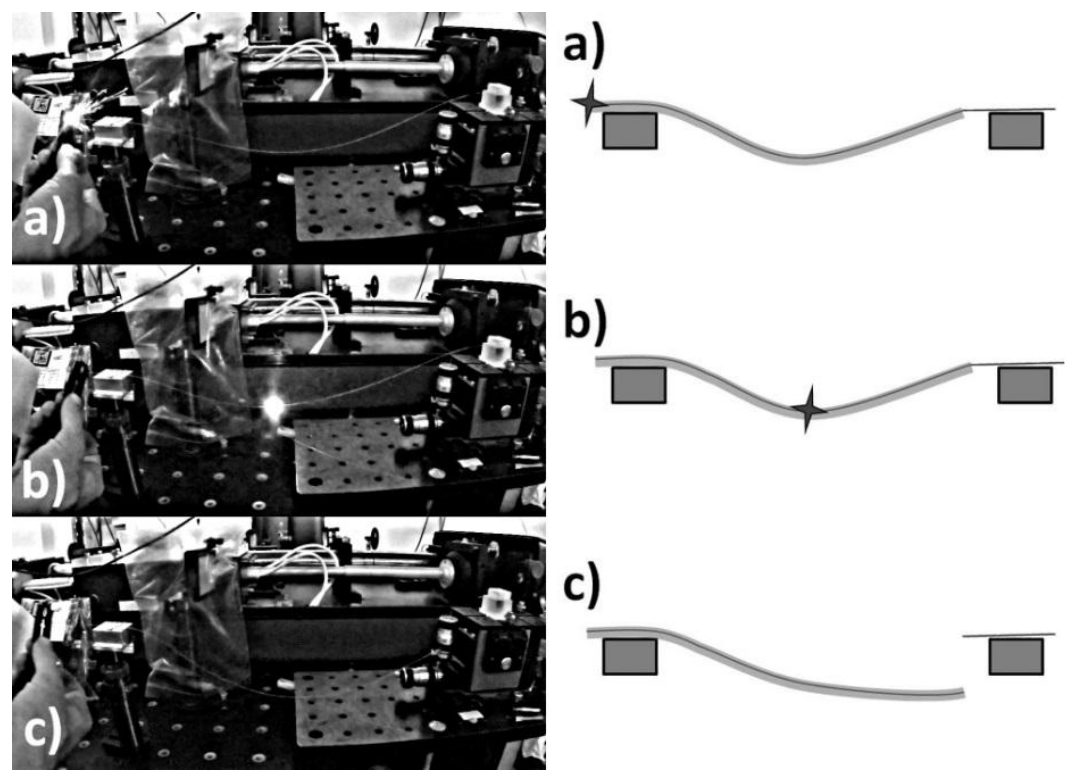

Рис.2 a) момент инициирования; b) момент движения светящейся волны разрушения по световоду; с) световод упал, оборвавшись по месту окончания полимерного покрытия.

Излучение лазера вводилось в полую сердцевину световода с эффективностью 72\%. Лазер работал в режиме одновременной модуляции добротности и синхронизации мод. Внутри импульса модуляции добротности (200 нс) проходили импульсы длительностью около 100 пс и частотой следования 76 МГц (около 15 импульсов за 200 нс). Процесс разрушения инициировался с помощью металлического лезвия, которое подносилось вплотную к выходному торцу световода (рис.2а). Перед «поджигом» световода на его выходе средняя мощность составляла 2 Вт, что соответствует пиковой мощности $1 \mathrm{MBT}$.

Как видно из рис.1с, диаметр области разрушений (трещин) лишь незначительно (на 30\%) превышает внутренний диаметр сплошной стеклянной оболочки (36 мкм). При использовании же световода с толщиной стеклянной оболочки 15 мкм (а не 31 мкм, как у световода на рис. 1a-d) трещины развиваются по всей толщине оболочки, и только внешний слой полимера позволяет ему сохранять свою форму. Когда же разрушение доходит до области без полимерного покрытия, то световод обламывается под собственным весом (рис.2). Полученные данные указывают на реализацию светодетонационного режима распространения оптического разряда по газу в сердцевине (аналогично [2]).

Работа была поддержана Российским фондом фундаментальных исследований (грант РФФИ 18-02-00324).

\section{Литература}

[1] R. Kashyap. Optics Express, 21, 6422-6441 (2013).

[2] A.A. Frolov, I.A. Bufetov et al. Proc. of SPIE 6193, 61930W (2006).

[3] E.M. Dianov, I.A. Bufetov et al. Electronics Letters, 38, 783-784 (2002). 